\title{
Gene Editing for Climate: Terraforming and Biodiversity
}

W.M. Adams, Department of Geography, University of Cambridge, CB2 3EN.

Email:wa12@cam.ac.uk

\begin{abstract}
This paper comments on the idea of engineering novel and artificial forms of life to combat anthropogenic climate change by 'terraforming' the Earth. The idea of 'Nature-based Solutions' that sustain biodiversity while supporting human well-being connects conservation and climate change. However, the technologies of synthetic biology, particularly geneediting, challenge the notion that only naturally-evolved organisms and ecosystems are capable of influencing in climate. The release of genetically-engineered organisms poses risks to biodiversity. Synthetic biology's engineering vision for the organic world is bold. But, terraforming with synthetic organisms is at odds with the conservationist's concern for living diversity and diverse ecologies.
\end{abstract}

Keywords

biodiversity, climate change, conservation, ecology, gene editing, nature-based solutions, synthetic biology, terraforming,

\section{Biodiversity and Climate}

Biodiversity loss and climate change are portrayed as the two linked crises of the Anthropocene (Rockström et al. 2009). But what links them? Less than many in conservation would like.

Conservationists often feel themselves poor relations in debates about global futures. They suffer a measure of 'climate change envy'. They lament the lack of headline numbers that can match the allure of atmospheric concentrations of $\mathrm{CO}_{2}$ (Zaccai and Adams 2012, c.f. Hulme 2020a). They envy the way the procession of reports from the IPCC (Intergovernmental Panel on Climate Change) for its creation of a powerful scientific consensus on climate change of a kind that has been slow to form for biodiversity, because they swallow without question the assumption that 'scientific facts' automatically drive 
policy change (a process that Mike Hulme (2011) has referred to as 'climate reductionism'). The Intergovernmental Science-Policy Platform on Biodiversity and Ecosystem Services (IPBES) is sometimes described as an attempt to 'do an IPCC' for biodiversity (e.g. Jowitt 2010), although it has a broader remit (to catalyse generation of new knowledge, support policy and build capacity, as well as assessing existing knowledge, Brooks et al. 2014).

The main point of agreement between those concerned about climate change and biodiversity loss is the importance of carbon storage in forests, peatlands and other ecosystems. When undisturbed, such habitats are often biodiverse, and conservationists have long argued the importance of their conservation as part of climate policy, for example through the tortuous byways of REDD and REDD+.

The latest way of framing this argument is based on the concept of 'Nature-based Solutions' (Cohen-Shacham et al. 2016). This emerged from the idea of ecosystem services, and refers to actions to address climate change (and other issues such as food and water security or natural disasters) that involve the protection, sustainable management or restoration of natural or modified ecosystems. It is argued that 'Nature-based Solutions' can sustain biodiversity at the ecosystem and species levels of such importance to conservation, while providing human well-being benefits (Cohen-Shacham et al. 2016). This wins area-based conservation programmes an important place in the fight against runaway climate change.

\section{Biodiversity and Terraforming}

Debates about biodiversity conservation and climate change are familiar territory. But new ideas challenge the notion that the only organisms and ecosystems that are useful in climate mitigation are those that evolved naturally. There is increasing interest in novel and artificial forms of life, epitomised by an article in the MIT Technology Review in 2016, entitled 'How Synthetic Organisms Could Terraform the Earth'. Its premise was that one way to combat climate change might be 'to release synthetic organisms that sequester carbon' (Anon 2016). This speaks to a quite different kind of biology, and a different vision of organisms and ecosystems, to those prioritized by conservationists.

The idea of terraforming is not new. In 1961 Carl Sagan discussed the "planetary engineering' of Venus to allow human habitation using microbes to break down carbon 
dioxide in the atmosphere. The term has retained currency in debates about making other planets habitable by humans, notably Mars (e.g. McKay et al. 1991). Recognition of human transformation of the earth's atmosphere of earth through climate change suggested the neat (if scary) possibility of whether the same trick could be pulled off on Mars to allow terrestrial life forms.

Jump forward a quarter of a century, and terraforming has come back to Earth as a way of describing geoengineering, the deliberate (as opposed to accidental) manipulation of the climate (Ridgewell et al. 2012). The difference this time is the advent of new technologies of synthetic biology.

\section{Synthetic Biology}

The field of synthetic biology, which began to come together around the year 2000, reimagines biology in engineering terms (Cameron et al. 2014, Carlson 2010). It involves both the design and construction of 'novel artificial biological pathways, organisms and devices' and the redesign of existing natural biological systems (Royal Society 2020).

It treats the genome as a resource, a raw material to be shaped to meet human ends (Gibson 2014). It frames biological life in terms of industrial processes, treating genetic sequences as standardized parts that can be engineered and reassembled into lengths of DNA that can stop, start or run a biological process in a predictable and standardized way. Synthetic biologists speak of combined DNA sequences as genetic circuits, and engineered cells and even organisms as 'devices'.

The transformative technology in synthetic biology is 'gene editing', using a range of techniques of which CRISPR-Cas9 is the best known. Science named CRISPR its 'breakthrough of the year' in 2015. In the language of to this familiar 'editing' metaphor, the order of bases in the DNA of an organism is 'read' and translated into a digital form using a sequencing machine. A new design is then created in a computer digital design (for example involving the removal or 'silencing' of particular sequences of bases or the insertion of new ones) using CRISPR or a related tool. The new digital design is then created physically in a DNA synthesis machine, and inserted into a living cell, which (hopefully) will then start to operate according to the new genetic instructions (Davies 2018). The precision and speed of 
this 'editing' process is increasing rapidly. By 2019 six differernt CRISPR cutting systems had been identified, with the potential toto cut and rebuild millions of genes at a time (Service 2019).

Reviews court hyperbole in describing the promethean potential of gene editing as a technique, and synthetic biology as an approach. Gene editing allows precise changes to be made to the genetic code of any organism, from bacteria or yeasts to mammals or trees. In principle, it can be used to alter any genetically-based biological attribute of any existing species. It can also be used to create completely novel genetic sequences, and potentially species wholly new to nature. In 2010, the science media announced (slightly prematurely) the creation of 'the world's first synthetic life form' on the back of work at the J. Craig Venter Institute in the USA who had synthesized a chromosome from one species of bacterium and transplanted it into another (Sample 2010, Gibson et al. 2010). Scientific progress in such experiments is rapid, and tasking place in many different countries.

The field of synthetic biology promises to transform and disrupt all industries based on biological systems, including crop and animal breeding, human and veterinary health, the manufacture of biologically based materials and industrial feedstocks (Morton 2019). It is receiving billions of dollars of government and private investment, particularly in the USA and China (NASEM 2017).

\section{Terraforming with Synthetic Life}

So, while the achievements of synthetic biology still fall short of ambition, the basic principles of genome editing are well established, and industrial and whole organism applications are common in commercial settings as well as research laboratoriess. This means that there is no reason, in principle, why terraforming using genetically engineered organisms could not be attempted.

Synthetic biologists, and futurologists working in the field, speak openly of living 'devices' designed explicitly to live in polluted or degraded environments, perhaps even to clean them up: living Wall-E robots, cleaning up Earth to make it safe for human habitation (e.g. Ginsberg et al. 2014). 
The extension of such thinking to the planetary scale, 'terraforming' of earth using synthetic biology, is not far-fetched by the standard of the field. The idea is to design, engineer and release synthetic microbial organisms that can self-replicate and colonize, reducing accumulated greenhouse gases, or reshaping the ecology of regions (such as desert margins) affected by climate change (Sole 2015, Solé et al. 2015). Novel engineered traits (salt or drought tolerance in plants, for example) could also be autonomously inserted into existing species, using a technique called a gene drive (Braverman 2016a).

The risks associated with this idea are recognized in the literature. Designed species would not thrive, or thrive too well and have unexpected effects. The release of synthetic organisms (or genetically engineered organisms) alarms many environmentalists, and is the subject of growing debate(e.g. Braverman 2016b), especially in biodiversity conservation (Redford et al. 2014, Phelps et al. 2019, Redford et al. 2019). The idea of terraforming using synthetic organisms is therefore deeply problematic from the perspective of biodiversity conservation.

Those mooting the idea of a world terraformed by synthetic organisms emphasize the need for careful contained experiments, and suites of computer models to try to predict what might happen at genetic, metabolic, population and ecosystem scales (Sole 2015). Genetic limits to the spreads or organisms could be built into the new engineered genomes (Solé et al. 2015). It remains un clear whether such measures are sufficient to address the risks, and who is to ensure such procedures are followed in a world without internationally agreed protocols to regulate the release of genetically engineered organisms (e.g. Braverman 2016b, Redford and Adams in press).

\section{Global Systems, Local Ecologies}

From a conservation perspective, the idea of terraforming with synthetic organisms is and extreme instance of the more general concern about the general release of synthetic organisms. However the idea of terraforming also offers another significant challenge to conservation challenge, in its lack of awareness of the problem of scale. The idea of terraforming as a strategy for managing greenhouse gas balances, assumes a single earth system. But biodiversity loss is a problem rooted in distinctive local ecologies. 
Biodiversity loss and climate change are both constructed as 'global problems', requiring 'global environmental management' (Adger et al. 2001). For biodiversity, that perception lies back in the age of European imperial conquest (Grove 1990, 1995): the national park became 'a kind of global brand long before Coca-Cola or McDonalds' (Gissibl et al. 2011, p. 14). Thinking about 'the environment' in global terms, relevant to the future of humankind as a whole, emerged in the twentieth century (Warde et al. 2018, Höhler 2015), and rose to prominence at the 1992 Rio Conference, which gave birth to both the UN Framework Convention on Climate Change and the Convention on Biological Diversity (Adams 2020). These in turn reflected earlier.

However, climate change and biodiversity loss differ in one critical respect, their geographies. Although the work of creating a global knowledge infrastructure, and developing a political response has distinctive geographies (Mahoney and Hulme 2018), the problem of climate change is understood globally, and synthesised in pan-global models. A reduction in carbon emissions anywhere on earth is equally effective in lowering atmospheric carbon concentrations (Brooks et al. 2014). It is possible to conceive of action in one place to remove carbon from the atmosphere (e.g. through tree-planting, or novel carbon capture technologies) having global benefits, for the atmosphere is understood (and modelled) as one connected system.

Biodiversity is different. The problem of biodiversity loss is distributed, because ecologies and species differ from place to place, as do human pressures upon them. The contributions of local reductions in biodiversity loss do not necessarily translate into globally-distributed benefits. Moreover, the conservation of biodiversity in one place does not necessarily benefit other species (or people) somewhere else.

From a conservation perspective, the biosphere cannot be treated simply like a physical machine for processing $\mathrm{CO}_{2}$, or any other pollutant. Releasing engineered organisms to drive changes in system parameters in the hope that they will make a difference to global climate system dynamics runs counter to all the evolved the principles of biodiversity conservation.

\section{Conclusion}


The release of synthetic organisms in the name of earth terraforming is a solution to climate changed that is based on nature. But it is a very different kind of nature to that an understood by conservationists, and set out in. the literature on 'Nature-based Solutions'.

The idea of terraforming, like geoengineering, is a classic ecological modernist response to climate change (Hajer 1995, Hulme 2014). It reflects the technophilia that permeates modernity, and confidence in 'accelerated technological progress' to deliver 'improved material well-being, public health, resource productivity, economic integration, shared infrastructure, and personal freedom' (Asafu Adjaye et al. 2015, pp. 30, 28). The white heat of innovation in synthetic biology makes it a natural partner for an eco-modernist approach to climate crisis.

Terraforming is a technological quick-fix, a scientists' dream of a brilliant, simple, radical solution to a specific problem. Its promise is Promethean, its vision of the biosphere dominated by a simplistic focus on physical parameters. The conservation and restoration of ecosystems (as promised in Nature-based Solutions) promises to deliver both global carbon sequestration services and local conservation benefits (by maintaining biodiversity). Terraforming would bring no such mix of benefits. It offers, at best, a cross-scale trade-off between imagined benefits to the carbon balance of the physical global ocean-atmosphere system and the real prospect of distributed biodiversity risks.

Synthetic biology's engineering vision for the organic world, the world of life, tracks seamlessly from genetic production lines via synthetic organisms and ecosystems to planetary carbon system dynamics. It is at odds with the conservationist's concern for living diversity and ecology. Many synthetic biologists are sanguine about the risks of radical intervention in natural systems. They do not share the ecologist's understanding of the biological world, one comprised of interconnected pieces interacting within living systems of dazzling complexity (Redford et. al. 2014). Terraforming with synthetic organisms invites the reflection that in the history of human manipulation of the biosphere, treatment is so often more damaging than the disease.

\section{References}


Adams, W.M. (2020) Green Development: environment and sustainability in a developing world: Fourth Edition, Routledge, London.

Adger, W. N., Benjaminsen, T.A., Brown, K., and Svarstad, H. (2001). Advancing a Political Ecology of Global Environmental Discourses. Development and Change 32: 681-715.

Anon (2016) 'How Synthetic Organisms Could Terraform the Earth', MIT Technology Review 6 April 2016, https://www.technologyreview.com/2015/04/06/168730/howsynthetic-organisms-could-terraform-the-earth/.

Asafu-Adjaye, J., L. Blomquist, S. Brand, B.W. Brook, R. Defries, E. Ellis, C. Foreman, D. Keith, M. Lewis, M. Lynas, T. Nordhaus, R. Pielke, R. Pritzker, J. Roy, M. Sagoff, M. Shellenberger, R. Stone and P. Teague (2015) An ecomodernist manifesto. Breakthrough Institute, Oakland, California

Braverman, I. (2016a) Gene drives, nature, governance: an ethnographic perspective, pp. 5573 in Braverman, I. (ed.) Gene Editing, Law and the Environment, Routledge, Abingdon.

Braverman, I. (2016b) (ed.) Gene Editing, Law and the Environment, Routledge, Abingdon Brooks, T.M., Lamorreux, J.F. and Soberón, J. (2014). IPBES $\neq$ IPCC. Trends in Ecology \& Evolution, 29 (10), 543-545.

Cameron, D. E., Bashor, C. J and Collins, J. J. (2014) A brief history of synthetic biology, Nature Reviews: Microbiology 12: 381-390

Carlson, R. H. (2010) Biology is Technology: The Promise, Peril, and New Business of Engineering Life, Harvard University Press, Cambridge.

Cohen-Shacham, E., Walters, G., Janzen, C. and Maginnis, S. (eds.) (2016) Nature-based Solutions to Address Global Societal Challenges. Gland, Switzerland.

Davies, J. A. (2018) Synthetic Biology: A Very Short Introduction, Oxford University Press, Oxford.

Gibson, D. G. (2014) Programming biological operating systems: genome design, assembly and activation, Nature Methods 11: 521-525

Gibson, D. G. Glass, J. I., Lartigue, C. et al. (2010) Creation of a bacterial cell controlled by a chemically synthesized genome, Science 329: 52-56.

Ginsberg A. D., Calvert, J., Schyfter, P., Elfick A. and Endy, D. (2014) Synthetic Aesthetics: Investigating Synthetic Biology's Designs on Nature, MIT Press, Cambridge MA.

Grove, R. H. (1990) 'The origins of environmentalism', Nature 345(6270): 11-14. 
Grove, R. H. (1995) Green Imperialism: colonial expansion, tropical island Edens and the origins of environmentalism, 1600-1800, Cambridge University Press, Cambridge.

Hajer, M. A. (1995) The Politics of Environmental Discourse: ecological modernization and the policy process, Oxford University Press, Oxford.

Höhler, S. (2015) Spaceship Earth in the Environmental Age 1960-1990, Taylor and Francis, London.

Hulme, M. (2011) Reducing the future to climate: a story of climate determinism and reductionism, Osiris 26, 245-266.

Hulme, M. (2014) Can Science Fix Climate Change? A Case Against Climate Engineering, Wiley, Chichester.

Hulme, M. (2020) Fetishising 'the Number': how not to govern pandemics, climate and biodiversity, Professor Mike Hulme's Site, 7 July 2020 (https://mikehulme.org).

Jowitt, J. (2010) 'France and Japan propose an 'IPCC for nature' Guardian (guardian,co.uk, Wednesday 9 June 2010).

Mahony, M. and Hulme, M., 2018. Epistemic geographies of climate change. Progress in Human Geography, 42: 395-424.

McKay, C.P., Toon, O.B. and Kasting, J.F. (1991) Making Mars habitable, Nature 352: 489496.

Morton, O. (2019) A whole new world, in: Redesigning Life: the Promise of Synthetic Biology, The Economist Technology Quarterly, 6 April 2019: 3-5, (p. 3).

NASEM. (2017) Preparing for Future Products of Biotechnology, The National Academies Press. Washington DC;

Phelps, M.P., Seeb, L.W. and Seeb, J.E. (2019) Transforming ecology and conservation biology through genome editing, Conservation Biology 34: 54-65.

Redford, K. H. and Adams, W.M. (in press) Strange Natures: Conservation in the Era of Synthetic Biology, Yale University Press, New Haven, NH.

Redford, K. H., Adams, W.M., Carlson, R., Mace, G., Cecarelli, B. (2014) Synthetic biology and the conservation of biodiversity, Oryx 48: 330-336.

Redford, K. H., Brooks, T. M., Macfarlane, N. B. W. and Adams, J. S. (eds.) (2019) Genetic Frontiers for Conservation: An Assessment of Synthetic Biology and Biodiversity Conservation. Technical Assessment, IUCN, Gland, Switzerland. 
Ridgewell, A., Freeman, C. and Lampitt, R. (2012) 'Geoengineering: taking control of our planet's climate?', Philosophical Transactions of the Royal Society A, 370: 41634165

Rockström, J., Steffen, W., Noone, K., Persson, Å., Chapin, III, F.S., Lambin, E., Lenton, T.M., Scheffer, M., Folke, C., Schellnhuber, H., Nykvist, B., De Wit, C.A., Hughes, T., van der Leeuw, S., Rodhe, H., Sörlin, S., Snyder, P.K., Costanza, R., Svedin, U., Falkenmark, M., Karlberg, L., Corell, R.W., Fabry, V.J., Hansen, J., Walker, B.H., Liverman, D., Richardson, K., Crutzen, C., Foley. J. (2009) 'A safe operating space for humanity', Nature 461: 472-5.

Royal Society (2020) Synthetic Biology, https://royalsociety.org/topicspolicy/projects/synthetic-biology/.

Sagan, C. (1961) The planet Venus: recent observations shed light on the atmosphere, surface and possible biology of the nearest planet, Science 133: 849-858

Sample, I. (2010) Craig Venter creates synthetic life form, The Guardian, 20 May 2010, available at: https://www.theguardian.com, (August 2020).

Service, R. F. (2019) Modified CRISPR cuts and splices whole genomes, Science 365: 849.

Solé R, Montañez R and Duran Nebreda S (2015) Synthetic circuit designs for earth terraformation, Biology Direct 10 (37) doi:10.1186/s13062-015-0064-7.

Solé, R. (2015). Bioengineering the biosphere? Ecological Complexity 22: 40-49.

Warde, P. Robin, L. and Sörlin, S., (2018) The Environment: a history of the idea, Johns Hopkins University Press, Baltimore MD.

Zaccai, E. and Adams, W.M. (2012) 'How far are biodiversity loss and climate change similar as policy issues?' Environment, Development and Sustainability 14: 557-571. 